\title{
B16 振子モデルに基づくハンマー投競技用アシストシステムの開発
}

Training aid system for hammer throw using pendulum model

\author{
○太田 憲（国立スポーツ科学センター）＼cjkstart梅垣 浩二（舞鶴工高専）＼cjkstart室伏 広治（中京大） \\ 小宮根 文子（国立スポーツ科学センター） 桜井 伸二（中京大）

$\begin{array}{ll}\text { Ken OHTA } & \text { JISS, 3-15-1 Nishigaoka, Kita, Tokyo 115-0056 } \\ \text { Koji UMEGAKI } & \text { Maizuru National College of Technology } \\ \text { Koji MUROFUSHI } & \text { Chukyo University } \\ \text { Ayako KOMINE } & \text { Japan Institute of Sports Science (JISS) } \\ \text { Shinji SAKURAI } & \text { Chukyo University }\end{array}$

\begin{abstract}
Dynamics-based force sensor using accelerometers which measures forces and joint torques has been developed. In this study we have applied this method to hammer throw training aid integrating small sensors, signal processing, short-range wireless transmission, data-logger and biofeedback training system. The purpose of this study was to establish methods for the measuring of rotational movement and the biofeedback training system for hammer throwers. Microelectromechanical systems accelerometers were chosen as the sensor platform capable of because they are noninvasive miniaturized devices and have wide bandwidth. In this system, a wireless data-logger was developed as a wearable device to replace cables and reduce constraint caused by wearing cables. The transmitted data were given as biofeedback information over a speaker through signal processing and voltage to frequency conversion.
\end{abstract}

Key word: Accelerometers, Biofeedback, Dynamics Model-based Sensor, Hammer, Training Aid

\section{1 はじめに}

スポーツバイオメカニクスの研究などによって様々な運 動スキルに関する研究が行われているが, 実際にそれらの 研究成果を選手にわかりやすく伝達することは困難なこと が多い。また，スキルトレーニングにおける選手に対する 指導方法は様々であるが，言語による指導やビデオなどに よって後から選手の運動のパフォーマンスを評価し指導す ることが多いが，選手とコーチの間で事前に獲得された情 報や共通感覚を共有していない場合は，ときとしてその情 報伝達が容易でない場合もある。

一方, 古くから医療や心理学の分野では自律神経系等の トレーニングと.してバイオフィードバック法が用いられて いる(1,2)。一般にバイオフィードバック法とは, 制御が 困難な体温や脳波などの生理学的な指標を計測し、対象者 にその情報をフィードバックして一般に困難な体内状態を 制御する方法をさす。このようなフィードバック方法は, 事前の知識共有も必要なく,バーチャルな感覚器官として 作用することによって，アクションを起こしながら，無意 識的に制御されている自律神経系等を意識的にトレーニン グすることができる．

そこで著者らは，運動スキルに関連した無意識下の情報 や直接感覚することのできない情報を，音や電気刺激など の情報に変換することによって，スポーツのスキル獲得の トレーニング方法としてのバイオフィードバック法を提案 している。また，これまでバドミントン・ラケットに装着し た加速度計を用いて計測した角速度情報をVF変換によって 音の情報に変換し，運動を行いながら情報をリアルタイム でフィードバックし，バドミントンのスキルトレーニング に応用した ${ }^{(3)}$ 。しかし，この方法ではラケットの角速度情 報をフィードバックしただけであった。そこで本研究では, スキルトレーニングにおける重要なのは運動のダイナミク スに関連する情報と考え，ダイナミクスを考慮した適切な 情報をオンラインでフィードバックするトレーニング・ア
シストシステムを開発することを目標とする。このアシス トシステムは,ダイナミクス計算に必要な運動学情報を計 測する複数の加速度計を用いたセンサとワイヤレスデータ ロガーから構成される。この情報をオンラインで選手にバ イオフイードバックすることによって，これがバーチャル な感覚器官として作用し, 無意識的・感覚的な学習を可能 として，効果的にトレーニングが作用する期待がある(4)

そこで本研究では, 適切にハンマーが加速しているかど うかをフィードバックするための，ハンマー投の回転の加 速原理を数理モデルと実験から検討し，そ机を適用したハ ンマー投用のトレーニング・アシストシステムの開発につ いて報告する。

2 バイオフィードバック・アシストシステム

ここでは，開発した加速度計を用いたハンマー投競技用 の計測・トレーニングアシスト・システムの概要を示す。

\section{1 計測原理}

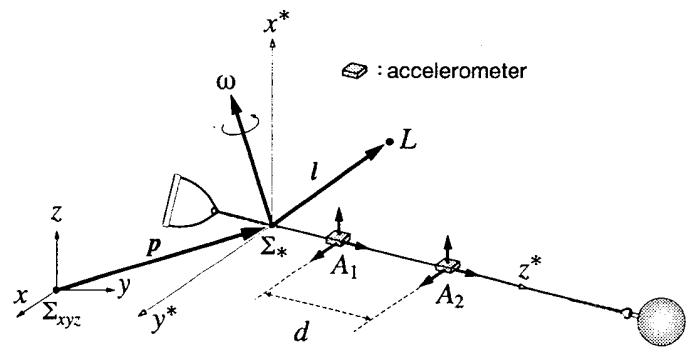

Fig. 1 Coordinate system

まず加速度計を用いた運動の計測方法の計測原理につい て述べる. Fig. 1に示したように，基準座標系 $\Sigma_{x y z}$ ら見た 移動物体（ここではハンマー）に固定された移動座標系 $\Sigma_{*}$ の原点の位置べクトルを $p^{*}$ と, 移動座標系 $\Sigma_{*} に$ 固定さ 
れた点 $L$ の位置ベクトルを $l^{*}$ とする。このとき, 点 $L$ の加 速度 $a^{*}$ は

$$
a_{L}^{*}=\ddot{p}^{*}+g^{*}+\dot{\omega}^{*} \times l^{*}+\omega^{*} \times\left(\omega^{*} \times l^{*}\right)
$$

となる。ここで, $g$ は重力加速度, $\omega$ は移動物体の角速度で あり，記号*は移動座標系で表現されていることを示す。 いま, 移動座標系 $\Sigma_{*}$ の $z^{*}$ 軸上に 3 軸加速度計 $A_{1}, A_{2}$ を平行 に配置する。ここで, 並進加速度成分 $\ddot{p}^{*}$ と重力加速度 $\boldsymbol{g}^{*}$ は, 平行に配置された $A_{1}, A_{2}$ に共に等しく検出されるの で, $A_{1}, A_{2}$ に検出される各加速度 $\boldsymbol{a}_{1}^{*}, \boldsymbol{a}_{2}^{*}$ の差は

$$
a_{12}^{*} \equiv a_{2}^{*}-a_{1}^{*}=\dot{\omega}^{*} \times l_{12}^{*}+\omega^{*} \times\left(\omega^{*} \times l_{12}^{*}\right)
$$

となる。ここで, $l_{12}^{*}$ は加速度計 $A_{1}$ から $A_{2}$ への位置べクト ルである。たとえば，Fig. 1のように $z^{*}$ 軸上に 3 軸加速度計 $A_{1}, A_{2}$ を平行に配置し, $A_{1}, A_{2}$ 間の距離を $d$ とし, 移動座標 系 $\Sigma_{*}$ で表現した移動物体の角速度べクトル $\boldsymbol{\omega}^{*}$ の成分を $\left[\begin{array}{lll}\omega_{x} & \omega_{y} & \omega_{z}\end{array}\right]^{T}$ とした場合, Eq. (2)の成分は,

$$
\boldsymbol{a}_{12}^{*}=d\left[\begin{array}{c}
\omega_{z} \omega_{x}+\dot{\omega}_{y} \\
\omega_{y} \omega_{z}-\dot{\omega}_{x} \\
-\left(\omega_{x}^{2}+\omega_{y}^{2}\right)
\end{array}\right]
$$

のように，間隔 $d に$ 比例した遠心加速度と角加速度になる。 したがって, 各座標軸上にある平行な 2 個の加速度計の差 をとることによって, 移動物体の加速度の回転運動成分を 取り出せる。

なお, Eq. (1) とEq. (2)から, 並進加速度と重力加速度の 和 $\ddot{p}^{*}+g^{*}$ も計測でき, これらの運動学デー夕と, 運動方 程式の質量・慣性モーメントなどの物理パラメータや幾何 学パラメー夕と併せて動力学計算を可能とする.またこの 計測方法によって得られる運動学デー夕は微分演算などを 含まず, 簡単な代数演算から計算され, かつ, 動力学計算 に必要な形式*1で直接運動学デー夕を計測できることか ら, 動力学計算に適した計測方法といえる.そこで, この ような複数の加速度計を用いたセンサを, 我々はダイナミ クスモデルベースの力覚センサと呼び(4), 運動中のそれ らのオンライン計測が可能となれば, 逆動力学に基づいた バイオフォードバックのみならず, 順動力学によるダイナ ミック・シミュレーションや, ゲーム機器などへの様々な 応用が期待される。

\section{2 ハンマー投用センサ基板}

Fig. 1に示すように, ハンマーのワイヤと移動座標系 $\Sigma_{*}$ の $z^{*}$ 軸を一致させ 3 軸加速度計 $A_{1}, A_{2}$ を $z^{*}$ 軸上に配置す る。ハンマー投運動の場合，投擲中の $\omega_{z}$ は小さく，

$$
a_{12}^{*} \approx d\left[\begin{array}{c}
\dot{\omega}_{y} \\
-\dot{\omega}_{x} \\
-\left(\omega_{x}^{2}+\omega_{y}^{2}\right)
\end{array}\right]
$$

と近似でき，このような物体の長軸回りの回転が少ない場合 は, それ以外の軸に加速度計を装着することを省略するこ とができる。また，ワイヤー軸上の任意の点 $e$ の加速度 $\tilde{a}_{e}$ は

$$
\tilde{\boldsymbol{a}}_{e}=\boldsymbol{a}_{1}+l_{1 e}^{*} \boldsymbol{a}_{12}^{*}
$$

から推定することが可能である。ここで, $l_{1 e}^{*}$ は $z^{*}$ 軸方向を 正とした加速度計 $A_{1}$ から点 $e$ までの距離である。

Fig. 2に示したように, センサ用基板には, MEMS加速 度計を2個（アナログデバイセズ社：ADXL278 (50G) $z^{*}$

\footnotetext{
*1 たとえば $\omega_{x} \omega_{y},\left(\omega_{x}^{2}+\omega_{y}^{2}\right),(\ddot{p}+g)$ のように.
}

軸, STMicoroerectronics 社 : LIS3L06AL (2G) $x^{*} y^{*}$ 軸) か ら構成される 3 軸加速度計を配置し, その加速度計間の距 離 $d$ を $100 \mathrm{~mm}$ とした. Eq. (4)から, $x^{*}$ 軸と $y^{*}$ 軸方向のペア の加速度計から角加速度が, 同様に $z^{*}$ 軸方向のペアの加速 度計から遠心加速度が計測可能となる。

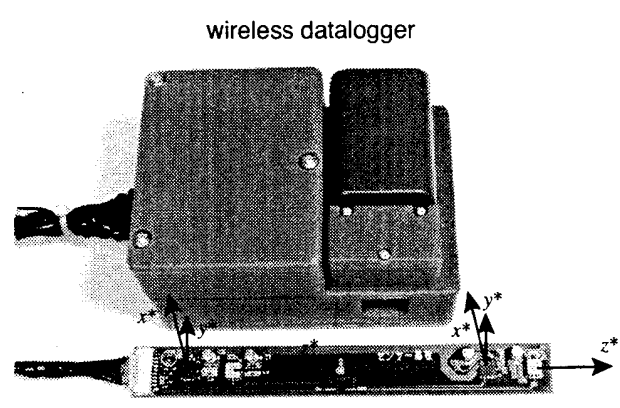

accelerometers

Fig. 2 Measurement system

2.3 無線データロガーとバイオフィードバックシステム

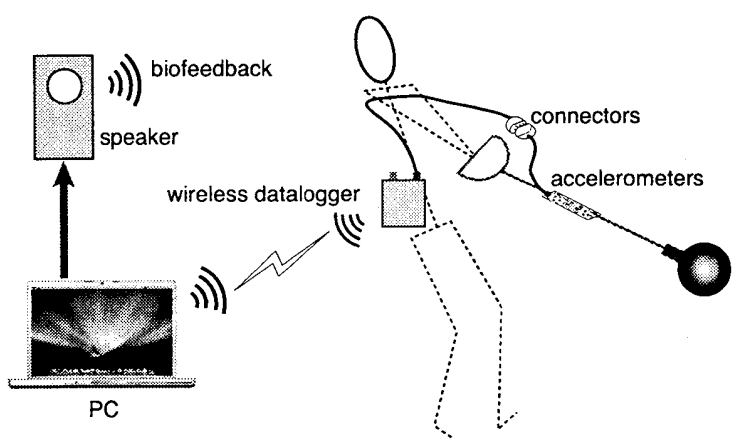

Fig. 3 Schematic illustration of biofeedback system

ケーブルなぞの拘束を少なくするために，アローセ ブン社と共同開発した小型無線データロガー（大きさ $100 \times 70 \times 55 \mathrm{~mm}, \max 1 \mathrm{kHz}, 12 \mathrm{bit}, 12 \mathrm{ch})$ に加速度計を 接続する (Fig. 2参照)。無線データロガーのに搭載した $2.4 \mathrm{GHz}$ 帯の無線機能を利用して, PCにオンラインでデー 夕を送信する。デー夕送受信等の命令には, PCから無線 またはUSBを経由したシリアル通信を用いる。加速度計を 搭載した基板はハンマーワイヤー部に固定され，データロ ガーとケーブルで接続される.PCで受信した加速度信号 は, Eq. (4)に基づいて角速度と角加速度に分離され，その 情報をオンラインで音の信号に変換し, 選手にバイオ・ フィードバックする (Fig.3)。なお, 小型無線データロ ガーにはメモリも内蔵され, 無線またはUSBを経由して データをオフラインで転送することも可能である。

\section{3 実験}

\section{1 実験方法}

Fig. 4に実験の風景を示す. 投撙時のハンマーの運動を 詳細に計測するため, モーションキャプチャシステム (Oxford Metrics社, 光学式動作解析システムVicon, カメ ラ12台，120Hz）と開発したハンマー投用センサと無線 


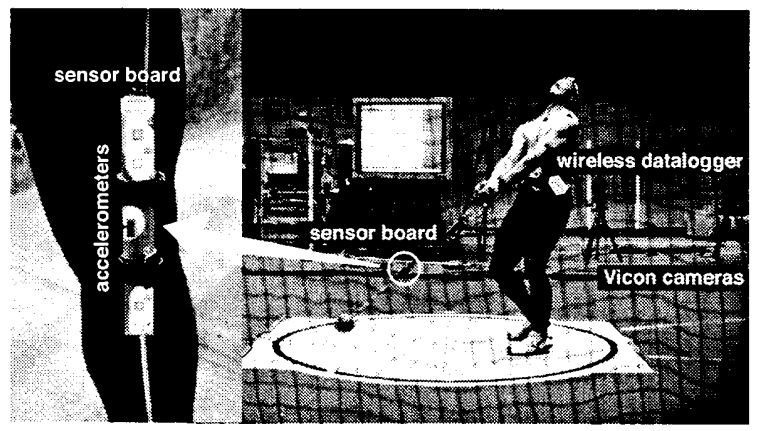

Fig. 4 Experimental setup

データロガーを用いてハンマー投擲実験を行った。ハン マー各部に反射マーカーを6個（ハンマーヘッド部3個，ワ イヤー部3個）装着し，モーションキャプチャシステムで ハンマーの運動を計測した。また, 加速度計を実装したセ ンサ基板をハンマーワイヤー部に装着し，投擲者の腰部に 装着したワイヤレスデータロガーに $200 \mathrm{~Hz}$ で記録した。セ ンサ基板とデータロガーはケーブルで接続されているが, リリース時にコネク夕部で切断される。また，計測中同じ $2.4 \mathrm{GHz}$ 帯の無線によって, 無線データロガーとモーショ ンキャプチャシステムの $\mathrm{AD}$ 変換器に同時にパルス信号を 送信し（誤差 $\mu \mathrm{sec}$ 以内），同期を行った。

実験では，大学陸上部のハンマー投競技者 4 名（男子 3 名，女子 1 名，競技歴 3〜6年）とアジア男子記録保持者 1 名 （競技歷18年）の計5名の被験者が，室内の陸上競技実験場 内の緩衝用カーテンに向かって投橂を行った。

3.2 実験結果: ハンマーの角速度と角加速度

a)

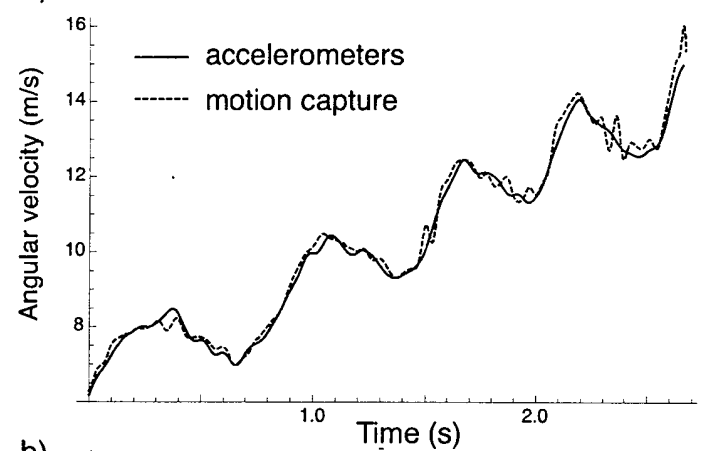

b)

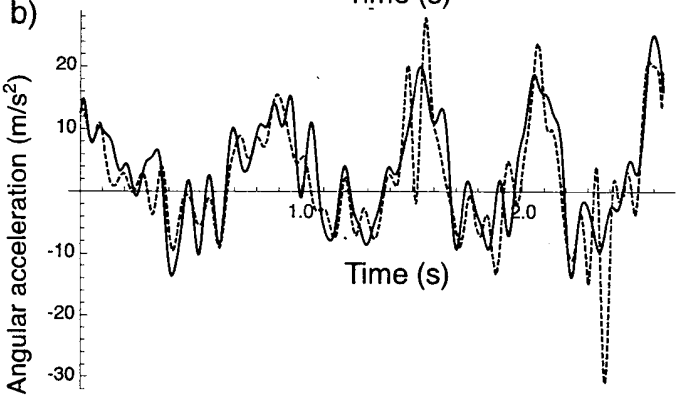

Fig. 5 Comparison of angular velocity and angular acceleration of hammer

計測した運動中のハンマーの角速度と角加速度の一例を Fig. 5 に示す. 実線は加速度計から計測した角速度 (a) と角
加速度 $(\mathrm{b})$ を, 破線はモーションキャプチャによって計測し たそれぞれを示す。このことから，加速度計から計測した 角速度と角加速度がほぼ一致していることがわかる。また， 同様に加速度計とジャイロから計測した角速度と角加速度の 比較からも，同様に一致した計測值が得られていることか ら (4)，加速度計を用いた計測方法の妥当性を示している。

またこの実験結果から，ハンマーは両足が接地している 而足期に加速し, 片足期に減速し, 角加速度の正負の変動 を繰り返しながら，全体的に角速度が振動的に增加してい ることが確認できる(5)。熟練者のハンマーの運動の瞬間 回転中心が大きく変動しないことからも, 運動はほぼ回転 運動から構成されていると考えることができ, 回転のエネ ルギーを蓄えていくことが重要と考えられる。

\section{4 八ンマーの加速原理の考察}

4.11 自由度振子モデル

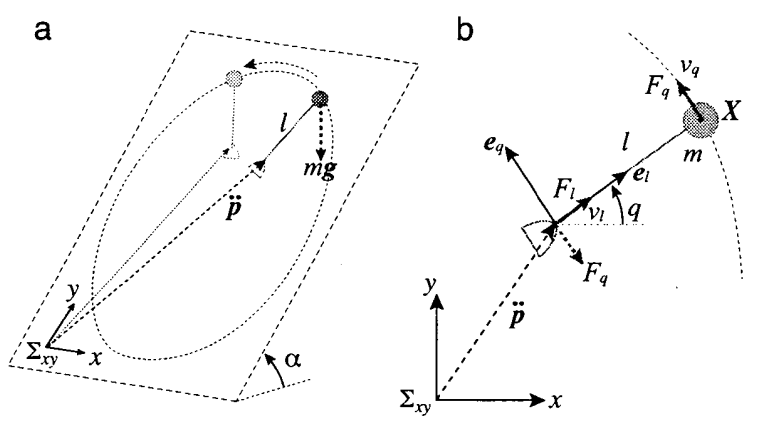

Fig. 6 Hammer model

選手に与えるフィードバック情報を検討するために，八 ンマーの運動をモデル化する．Fig.6に示すような，1自由 度振子モデルを考え, 単純化のためハンマーは角度 $\alpha て ゙$ 傾 いた平面内を運動していると仮定する．Fig.6bはこの平面 内でのハンマーの位置関係を示したもので, この平面内の $x y$ 座標で定義された基準座標系 $\Sigma_{x y}$ を定義する. ハンマー ワイヤーは質量を無視した伸縮のないワイヤーで，ハン マーヘッドは質量 $m$ の質点とする。ハンマーのハンドル部 分からハンマーヘッドまでの距離をlとし, ハンマーと $x$ 軸 のなす角度を $q$ とする。またハンドルの位置べクトルを $\boldsymbol{p}=\left[x_{0}, y_{0}\right]^{T}$ とし，ハンドル部分は加速度 $\ddot{\boldsymbol{p}}$ で運動する。

以上の条件の下での, ハンマーの振子型モデルを考え る.ハンマーヘッドの位置ベクトル $\boldsymbol{X}$ は,

$$
\boldsymbol{X}=\boldsymbol{p}+l e_{l}
$$

その速度は

$$
\dot{X}=\dot{p}+l \dot{q} e_{q}
$$

となる。ここで $e_{l}=\left[\begin{array}{ll}\cos q, & \sin q\end{array}\right]^{T}, e_{q}=\left[\begin{array}{lll}-\sin q, & \cos q\end{array}\right]^{T}$ は, 各法線, 接線方向の単位べクトルである。このときの 運動エネルギーTとポテンシャルエネルギーUは

$$
\begin{aligned}
T & =\frac{1}{2} m \dot{\boldsymbol{X}}^{T} \dot{\boldsymbol{X}} \\
& =\frac{1}{2} m\left(\dot{x}_{0}^{2}+\dot{y}_{0}^{2}+l^{2} \dot{q}^{2}+2 l \dot{q} \boldsymbol{e}_{q}^{T} \dot{\boldsymbol{p}}\right) \\
U & =m g \sin \alpha\left(y_{0}+l \sin q\right) \equiv m g_{\alpha}\left(y_{0}+l \sin q\right)
\end{aligned}
$$

となり，上式をラグランジュの運動方程式

$$
\frac{d}{d t}\left(\frac{\partial L}{\partial \dot{q}}\right)-\frac{\partial L}{\partial q}=0
$$


に入れ，

$$
m l \ddot{q}=-m \boldsymbol{e}_{q}^{T}\left(\ddot{\boldsymbol{p}}+\boldsymbol{g}_{\alpha}\right)
$$

を得る。ここで, $L=T-U, \boldsymbol{g}_{\alpha}=\left[0, g_{\alpha}\right]^{T}$ である.この式 より, ワイヤーに直交する $e_{q}$ 方向の加速度がハンマーの回 転の加速度を左右する条件であることを示しており，この 回転方向だけに着目すれば, 符号よりハンマーヘッドと反 対方向に加速度を与えることが条件となることがわかる。

運動方程式から確認したこの加速条件を, 実際のハン マーの運動で確認する. Fig. 7 に Eq. (12)における, ハン マーヘッドの加速度の接線方向成分 $l \ddot{q}$ と, ハンマーハンド ル部の反対方向の加速度 $\boldsymbol{e}_{q}^{T}\left(\ddot{p}+g_{\alpha}\right)$ 比較した。ここでハン マーヘッドの加速度は加速度計から計測し, ハンドル部の 加速度はモーションキャプチャ・システムから計測した值 を用いている。この図からも, 回転方向のハンマーヘッド の加速が，ハンドル部の接線方向の加速度に依存している ことがわかる。

次に, ハンマーの加速条件をエネルギーレベルで考察 する。

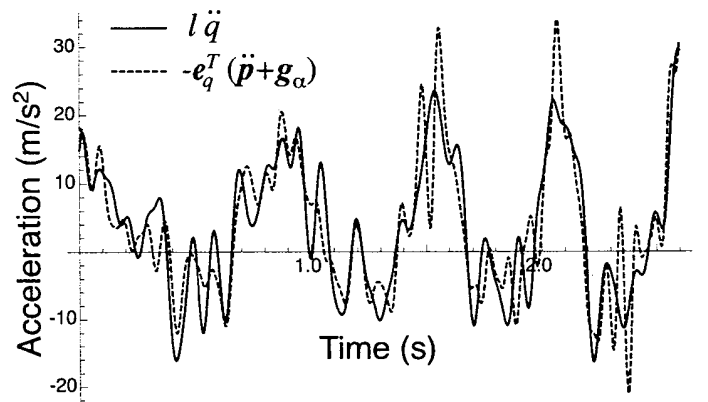

Fig. 7 Acceleration for rotational movement

4.2 加速条件 1: 力学的エネルギー

ハンマーヘッドの運動エネルギーTとポテンシャルエネ ルギーUの和

$$
E_{M}=T+U
$$

を微分し，Eq. (12)を考慮して，

$$
\dot{E}_{M}=F_{l} v_{l}
$$

を得る、ここで

$$
\begin{aligned}
F_{l} & \equiv m \boldsymbol{e}_{l}^{T}\left(\ddot{\boldsymbol{p}}+\boldsymbol{g}_{\alpha}\right)-m l \dot{q}^{2} \\
v_{l} & \equiv \boldsymbol{e}_{l}^{T} \dot{\boldsymbol{p}}
\end{aligned}
$$

である。これょり, 全力学的エネルギーを考慮してハン マーを加速するためには $\dot{E}_{M}$ を最大化することが必要とわ かるが, Fig. 6bにも示したように， $\dot{E}_{M}$ を構成する $F_{l}$ は八 ンマーの法線方向の加速力を, $v_{l}$ は法線方向の速度を意味 し,これらの積である法線方向のパワーがハンマーヘッド の加速条件となっている.

実際のハンマーの運動では, Eq. (15)の遠心力 $m l \dot{q}^{2}$ が大 きいため, ハンマーの力学的エネルギーを増加させるため には， $e_{l}$ の逆方向の力と速度を与えること，すなわちハン ドル方向に引っ張ることが必要となる。

また，この条件 1 を考慮した加速度信号によるフィード バック方法を実現する場合， $F_{l}$ と $v_{l}$ を計測する必要があ り,これはEq. (5)を用いて推定するハンドル部の法線方向
の加速度と質量 $m$ の積が $F_{l}$ に相当し，ハンマー用センサに よって力 $F_{l}$ を計算することが可能であることがわかる。た だし，ハンマーハンドル部分の法線方向速度 $v_{l}$ は加速度計か ら単純に推定することができないため，今後の課題である.

\section{3 加速条件 2 : 回転運動エネルギー}

ハンマーの運動のほとんどが回転運動から構成されるた め, 回転の運動エネルギーだけを加速の条件として考慮す ることもできる。同様に, ハンマーヘッドの回転の運動エ ネルギー

$$
E_{R}=\frac{1}{2} m l^{2} \dot{q}^{2}
$$

を微分し，Eq. (12)を考慮して，

$$
\dot{E}_{R}=F_{q} v_{q}
$$

を得る。ここで

$$
\begin{aligned}
F_{q} & \equiv m l \ddot{q}=-m \boldsymbol{e}_{q}^{T}\left(\ddot{\boldsymbol{p}}+\boldsymbol{g}_{\alpha}\right) \\
v_{q} & \equiv l \dot{q}
\end{aligned}
$$

であり, Fig. 6bに示したように, $F_{q}$ はハンマーの接線方向 の加速力を, $v_{q}$ は接線方向の速度を意味し, これらの積で ある接線方向のパワーがハンマーヘッドの加速条件となっ ている。なお，ハンマーの角速度の変化が滑らかで大きな 変化がなく, ハンマーの制御がハンドル部分で行われると 仮定すると, $\dot{E}_{R}$ の最大化のためには, $F_{q}$ の最大化, すな わちハンドル部分の接線方向の加速度成分の最大化が, 考 慮すべき加速条件となる。

また，この条件 2 を考虑した加速度信号によるフィー ドバック方法を実現する場合， $F_{q}$ すなわち， $\ddot{q}$ むしくは $\ddot{p}+g_{\alpha}$ を計測する必要があるが，第 2.2 節で述べたように， センサから計測される, Eq. (4)の $\dot{\omega}_{x}$ と刻の合ベクトルが $\ddot{q}$ に相当し, Eq. (5)を用いて推定するハンドル部の加速度が $\ddot{p}+g_{\alpha}$ に相当し, 加速条件 2 を計算するための運動学デー タがハンマー用センサで計測可能であることがわかる.

4.4 八ンマーのエネルギー変化

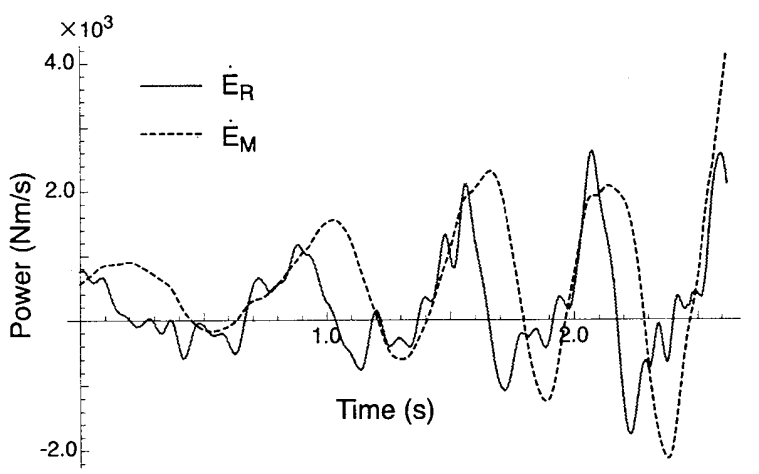

Fig. 8 Comparison of power for hammer movement

Fig. 8に, 投擲中のハンマーのエネルギー変化率を示し た。ここで, $\dot{E}_{M}$ は力学的エネルギー全体の変化率を, $\dot{E}_{R}$ は回転エネルギーだけの変化率を示している。実際のハン マーの運動では, ハンドル部分も比較的大きな速度を持つ ことから, Eq. (14)と Eq. (18)に違いが生じており, 主と してこれは法線方向の腕からハンマーへのエネルギー伝達 による影響といえる。 
前述したように，加速条件2でフィードバックする場合 は，センサ基板の加速度計の情報だけからのフィードバッ クが可能となるが, 加速条件1でフィードバックする場合, ハンドル部の速度 $v_{l}$ を何らかの方法で計測する必要が あり，2リンク機構モデルを考えるなどして，さらなる フィードバック方法の検討が必要となる。

なお，ハンマーを加速する条件をエネルギーレベルで考 察すると, 回転の運動エネルギー $E_{R}$ は力学的エネルギー $E_{M}$ に含まれる。しかし，力べクトルと速度べクトルの内 積であるエネルギー変化率（パワー）レベルで比較する と, $\dot{E}_{R}$ を構成する $F_{q}$ と $v_{q}$ は接線方向のベクトルから，ま た $\dot{E}_{M}$ を構成する $F_{l}$ と $v_{l}$ は法線方向のベクトルから構成さ れて，これらの向きは直交している，両者の関係は独立で はないが，ハンマーの回転エネルギーを増加させるために はハンドル部に接線方向と逆向きの加速度を, 全力学的工 ネルギーを増大させるにはハンドル部をワイヤ軸方向に 引っ張る方向に加速度を与えることが条件となり，両方の 情報をフィードバックする方法も検討すべきである．投擲 中のハンドル部の各加速度成分をFig. 9に示した。これま で述べてきたように，接線方向では加減速を繰り返してい るが，ワイヤー軸方向ではハンドルを身体の方向にほぼ一 定の加速度で引つ張り続けていて，ハンマーの曲率半径も 次第に短くなっている(6).

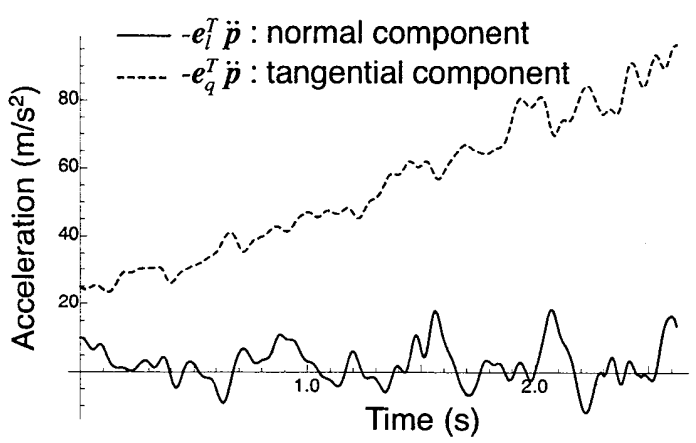

Fig. 9 Accelerations of hammer handle

\section{5 おわりに}

ハンマー投競技では，選手はハンマーワイヤー部に作用 する張力を直接感じることができるが，遠心力（角速度の 二乗）が大半を占め, ハンマーの加速の程度を示す角加速 度の情報が埋もれてしまい感じることができず，努力感の 割にはハンマーが効率よく加速していないなどの問題が生 じる、そこで本研究では，ハンマーを効率よく回転させる ための学習やトレーニングをアシストする道具として，加 速度計をべースにした力覚センサを開発した。このセンサ 基板はハンマーワイヤー軸上の任意の場所に装着し，ワイ ヤ一軸上の任意の加速度信号を推定することを可能として いる．また，ハンマーに作用する角加速度や遠心加速度，ま た並進の加速度なども分離することができ，これらの情報 はダイナミクス計算に適しているという特徴がある。すな わち，オンラインで運動中の身体や道具に作用する内力や トルクを計測するためのダイナミクスモデルベースの力覚 センサとして機能するが，ここでは，無線データロガーとあ わせて利用し，バイオフィードバックによるトレーニング アシストシステムを開発した。また, 運動中のそれらのオ ンライン計測が可能であるので, 動力学計算に必要なすべ
ての運動学データが加速度計から計測することができ, 動 力学モデルを介在させて,ダイナミック・シミュレーショ ンのための入力デバイスなど様々な応用が期待される。

一般に，回転運動を計測するセンサとしてジャイロが存 在するが，スポーツのような高速な運動を計測することが 困難である。また，ジャイ口の信号から角加速度を算出す る場合，微分の数值演算によるノイズが生じる。一方，本 研究で用いた計測方法では加速度計の差の信号用いている ことにより，微少振動などのノイズをキャンセルする特徵 から, 高精度な角速度と角加速度の同時計測を可能として いる $(7,8)$.

現在 1 リンク機構を用いて考察を行っているが, 今後は, 腕のリンクを考慮した 2 重振子モデルや, 最適制御問題な どから，より適切なフィードバック情報を検討していく. また，現在，音情報を用いてフィードバックする機構を採 用しているが，試験を繰り返すことによって，選手にとっ て学習しやすい方法方法をさらに検討していきたい．特に FES (機能的電気刺激) 法など直接筋肉を刺激する方法の 検討も行う予定である。

\section{参考文献}

(1) 西村千秋. バイオフィードバック. $B M E$, Vol. 2, pp. 618-625, 1988.

（2）西村千秋. バイオフィードバックに抢ける訓練過程の数理モデル. バイオフィードバック研究, Vol. 21, pp. 14-21, 1994.

（3）太田憲; 小林一敏; 上居陽治郎．加速度信号に上る運動の分析方 法. 日本機械学会スポーツ工学シンポジウム 1990 講演論文集, pp. $26-29,1990$.

(4) Ken Ohta, Koji Umegaki, Koji Murofushi, Ayako Komine, and Chikara Miyaji. Dynamics-Based Force Sensor Using Accelerometers -Application of Hammer Throw Training Aid-, Vol. 1 of The Engineering of Sports 7, pp. 207-213. Springer, Paris, 2008.

(5) Koji Murofushi, Shinji Sakurai, Koji Umegaki, and Junji Takamats. Hammer acceleration due to thrower and hammer movement patterns. Sports Biomechanics, Vol. 6, No. 3, pp. $301-314,2007$.

(6) Koji Murofushi, Shinji Sakurai, Koji Umegaki, and Kazutoshi Kobayashi. Development of a system to measure radius of curvature and speed of hammer head during turns in hammer throw. International Journal of Sport and Health Science, Vol. 3, pp. 116-128, 205.

（7）太田憲; 小林一敏. 加速度計を用いたスポーツにおける角速度・ 角加速度計測. 計測自動制御学会論文集, Vol. 30 , No. 12 , pp. 1442-1448, 1994

（8）太田憲; 小林一敏. 抬張カルマンフィルタを用いたスポーツにお ける角速度 ・角加速度計測. 計測自動制御学会論文集, Vol. 31, No. 9, pp. 1265-1272, 1995. 